MIRO HEGEDIĆ, Ph.D. ${ }^{1}$

(Corresponding author)

E-mail: miro.hegedic@fsb.hr

NEDELKO ŠTEFANIĆ, Ph.D. ${ }^{1}$

E-mail: nedeljko.stefanic@fsb.hr

MLADEN NIKŠIĆ, Ph.D. ${ }^{2}$

E-mail: mniksic@fpz.hr

1 Department of Industrial Engineering

Faculty of Mechanical Engineering and Naval Architecture,

University of Zagreb, Ivana Lučića 5, 10000 Zagreb,

Croatia

2 Department of Railway Transport

Faculty of Transport and Traffic Sciences,

University of Zagreb, Vukelićeva 4, 10000 Zagreb, Croatia
Traffic and Environment (Ecology) Original Scientific Paper

Submitted: 9 Feb. 2017

Accepted: 11 Apr. 2018

\title{
ASSESSING THE ENVIRONMENTAL IMPACT OF THE SELF-PROPELLED BULK CARRIAGE THROUGH LCA
}

\begin{abstract}
Environmental sustainability of the transport sector is a highly important issue today. The European Commission has made a goal of delivering a minimum $60 \%$ reduction in greenhouse gas emissions from transport by 2050. Part of this reduction will come from the railway sector by making the maintenance processes more environmentally friendly. This paper presents the results of the environmental assessment of the self-propelled bulk carriage (SPBC), an innovative new product aiming to decrease the environmental impact of the railway maintenance processes. The life cycle assessment (LCA) methodology was used in the study, and environmental impact is given in five impact categories based on the CML 2001 method through three main modules of the self-propelled bulk carriage life cycle: upstream, core, and downstream. The novelty of the research includes the fact that this is the first life cycle assessment study done for the bulk carriage, as well in that the authors have proposed the use of a new functional unit in the category of freight railway vehicles. The biggest environmental impact of the self-propelled bulk carriage across all five categories is in the use and maintenance phase of its life cycle and mainly due to diesel fuel use. The SPBC uses significantly less fuel than a conventional diesel locomotive.
\end{abstract}

\section{KEY WORDS}

self-propelled bulk carriage; life cycle assessment; freight rolling stock;

\section{INTRODUCTION}

Environmental sustainability of the transport sector is a highly important issue today. The European Commission has made a goal of delivering a minimum $60 \%$ reduction in greenhouse gas (GHG) emissions from transport by 2050 with respect to 1990 [1], [2]. To achieve this overall goal, rail transportation will play an important role as well, especially in the area of freight transport, which will result in a number of activities required in the area of railway construction, maintenance, and repair. Therefore, railway sector could expect considerable changes in the future. Those changes are not going to influence only the development of new, environmentally friendly transportation means but also their impact through the whole life cycle, including the use and maintenance of the supporting infrastructure.

The EU-28 railway transport network consisted of $220,000 \mathrm{~km}$ of railway lines in 2013 , and when the railway systems of China, Russia, Japan, and USA are added to this number, it grows to $634,200 \mathrm{~km}$ [3] that need to be maintained. Railway construction maintenance and repair are resource-demanding activities that have a considerable impact on the environment, especially when diesel locomotives are used for shunting bulk carriages, because materials delivered to construction sites need to be unloaded at various points along the tracks. Nowadays, because of the technical characteristics of bulk carriages, three locomotives have to be used to maneuver them, where one locomotive has to work constantly either in standby mode or actively shuffling the carriages. The carriages are delivered to the unloading site one by one, requiring other equipment and human resources to be engaged significantly throughout the process. Therefore, as a resource, the locomotive is taken up all day although its services may be needed only for a couple of minutes every hour.

The increased volume of work seeks for an innovative approach to solving current problems while having in mind the perennial need to decrease the environmental impact. It is the role of innovation to promote sustainable development. That is why Croatian company RŽV Čakovec has developed an innovative 
product named the self-propelled bulk carriage (SPBC) that can improve the environmental impact of railway construction, maintenance, and repair activities. The SPBC is a self-propelled bulk carriage that has the capability to move on rails using its own traction system and is operated via remote control. Although it uses less energy to operate compared to three diesel locomotives, the SPBC has a certain environmental impact throughout its life cycle.

To assess the environmental impact of the SPBC, life cycle assessment (LCA) [4] methodology was used. In the railway industry, a product's life cycle is divided into three core modules: (1) upstream, (2) core, and (3) downstream. The downstream module is further divided into two phases: (a) use and maintenance (UaM), (b) end of life (EoL) phase. LCA provides a systematic profile of environmental burden over the life cycle of a product and includes energy, material, and waste flows associated with the product, as well as their environmental impact [5]. It allows us to model the environmental impacts in numerous categories.

To assess the environmental impact of rail vehicles, several studies have used LCA in different projects and countries across the globe, such as Belgium [6], China [7], Germany [8], Sweden [9],[10], Korea [11], Switzerland [12], Norway [13], Turkey [14], USA [15], Italy [16], Portugal [17]. However, LCA has not been performed for any rail bulk carriage.

This paper presents the results of the LCA study of the SPBC. It is the first LCA for the self-propelled bulk carriage in the world. The study aims to assess the total life cycle environmental impact of the self-propelled bulk carriage, which is built as a prototype product with the aim to make railway construction, maintenance, and repair more environmentally friendly. This study has not been done as a comparison, so there is no comparative analysis between this LCA and the results of different LCAs because of two reasons: (1) there is no study that has assessed the environmental impact of the bulk carriage, and (2) the first aim of the study was to obtain environmental data for the prototype product of the self-propelled bulk carriage.

Quantification of environmental performance in LCA studies is most often based on rules defined within the study by the authors or study commissioners, which makes it difficult to compare the results of studies concerning a similar product unless both studies are based on the same rules, which is often not the case [18]. To make studies more comparable, a growing body of standards has been developed under the name product category rules (PCR) [19]. PCR provides guidance for companies that have to embark on the journey of creating LCA reports for their products so they can obtain and publish environmental data which are comparable to similar products or a group of products. PCRs are defined in ISO 14025:2006 [20] as a set of specific rules, requirements, and guidelines for developing Type III environmental declarations (environmental declaration providing quantified environmental data using predetermined parameters and, where relevant, additional environmental information) for one or more product categories (group of products (any goods or service) that can fulfil equivalent function). The general LCA methodology used in this study is based on ISO 14040:2006 [21], ISO 14044:2006 [22], and ICDL Handbook [23]. In order to analyze environmental impact, the CML2001 (baseline) method is used.

The function of the studied system is delivery of construction material to the site and unloading of the needed amount of material precisely where it is going to be used. Therefore, in the life cycle interpretation part of this study, the functional unit of 1 ton per 1 kilometer (tkm) is used. However, the use of the functional unit of 1 ton per 1 working hour would be more suitable for this kind of self-propelled vehicles.

The novelty of this research is that no similar study has been carried out for the bulk carriage, as well that the authors have proposed the use of a new functional unit in the category of freight railway vehicles. The present work is different from others because it provides new insights into how innovative approach to railroad maintenance can lower the environmental impact of railroad maintenance activities. The paper is structured as follows: in section two, the methodological approach is defined; section three presents results of the study; in section four, a discussion is given; and, finally, the conclusions are presented in section five.

\section{LIFE CYCLE ASSESSMENT METHODOLOGY}

Life cycle assessment is a science-based, comparative analysis and assessment of the environmental impacts of product systems [4]. Life cycle assessment was developed as an analytical tool to help assess the environmental impacts of products or services [24]. The holistic system's perspective which is applied in LCA [24] makes it a valuable decision support methodology in companies that want to develop their activities in an environmentally friendly direction. LCA is an iterative technique, and sometimes information defined in the first phase have to be updated accordingly. Life cycle assessment has its roots in the 1960s and early 1970s [24], when the first study focusing on environmental impacts from different types of beverage containers took place in the USA. An LCA comprises four main phases according to the ISO 14040 [21] standard: (1) Goal and scope definition, (2) Inventory analysis, (3) Impact assessment, (4) Interpretation, as shown in Figure 1. 


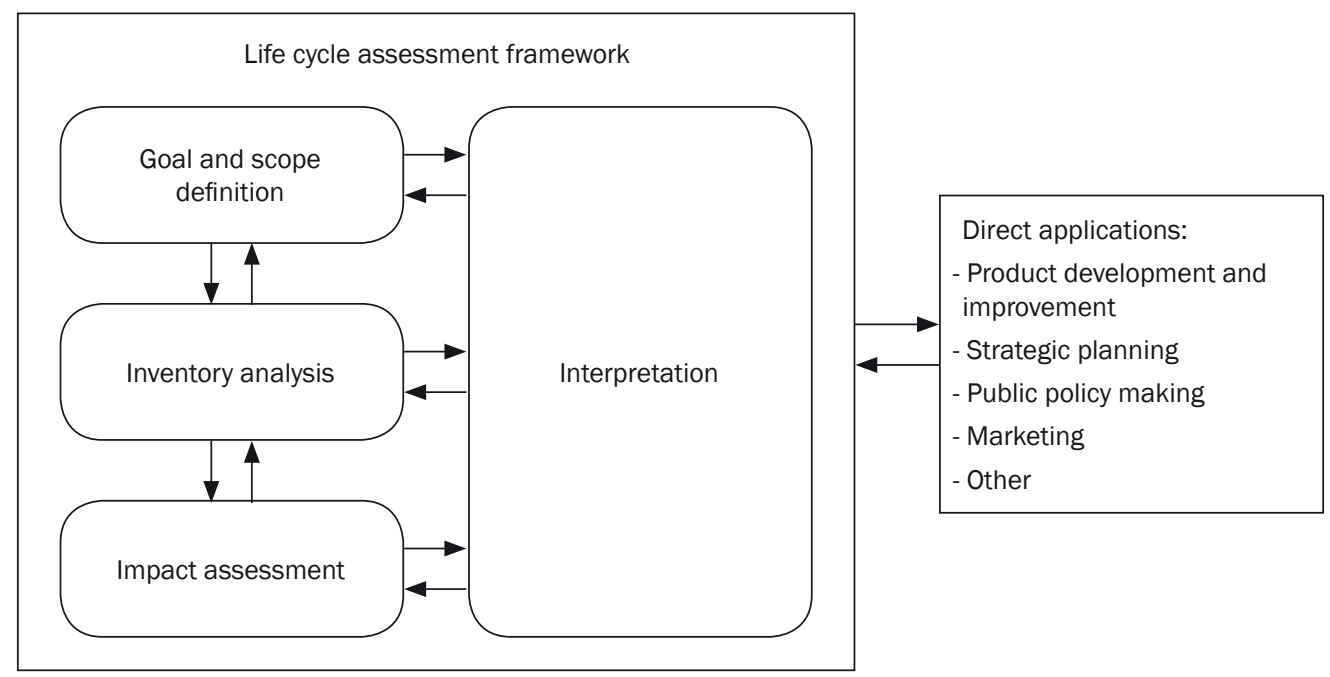

Figure 1 - Life cycle assessment framework [21]

\subsection{Goal and scope definition}

The first step of an LCA is to give the background for the study and provide data such as intended application, reasons for carrying out the study, intended audience, product system to be studied, data quality, system boundaries, impact categories, functional unit, etc. [4], [21]. A more detailed set of rules that have to be used when conducting an LCA study can be found in other standards that are referencing ISO 14040 , such as environmental product declaration (EPD), also called "Level 3" labelling [4]. The goal and scope phase defines the context of the study and includes technical details needed for the study.

The goal of this study was to assess the environmental impact of the self-propelled bulk carriage shown in Figure 2. The study serves as a background for the environmental product declaration.

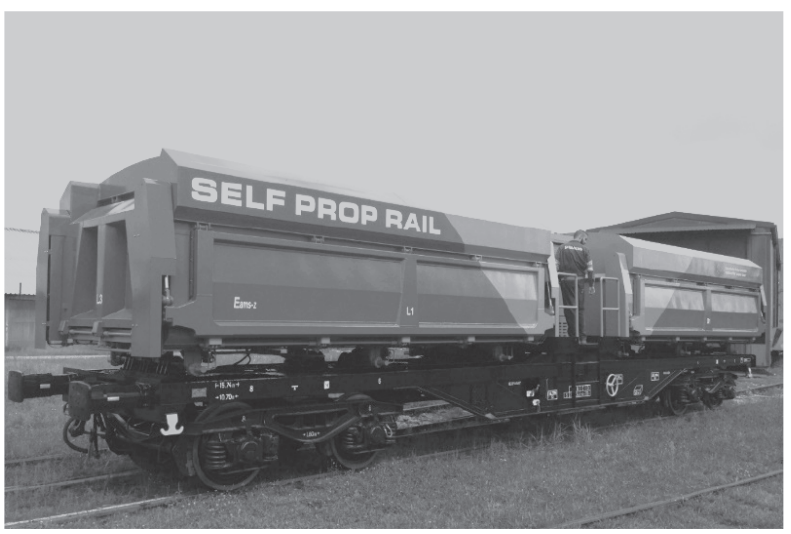

Figure 2 - Self-propelled bulk carriage (SPBC)

Regarding the functional unit, the PCR [19] for rolling stock distinguishes passenger rolling stock and freight rolling stock. The SPBC fits into the category of freight rolling stock. The functional unit for freight rolling stock is the transport of 1 ton for $1 \mathrm{~km}$, therefore the functional unit for this study is defined as: "one ton of transported and unloaded material per kilometer". In a study of the environmental performance of the Bothnia Line in Sweden [9], the same functional unit was used to allocate freight transport. In this study, reference flow is given as one SPBC. The technical specification of the studied self-propelled bulk carriage is given in Table 1.

Table 1 - Technical specification of the carriage

\begin{tabular}{|l|l||}
\hline \hline Type of bogie & Y25 Lsd-1 \\
\hline Compressed air brake & Yes (KNORR) KE-GP-A-2x10“ \\
\hline Slack adjuster & DRV2A-45OH \\
\hline Number of axles & 4 \\
\hline Axle load & $22.5 \mathrm{t}$ \\
\hline Tare mass & $37.34 \mathrm{t}$ \\
\hline $\begin{array}{l}\text { Max. mass of loaded } \\
\text { wagon }\end{array}$ & $90.0 \mathrm{t}$ \\
\hline Cargo mass & $52.66 \mathrm{t}$ \\
\hline $\begin{array}{l}\text { Max. speed of empty } \\
\text { wagon }\end{array}$ & $100 \mathrm{~km} / \mathrm{h}$ \\
\hline $\begin{array}{l}\text { Max. speed of full loaded } \\
\text { wagon }\end{array}$ & $100 \mathrm{~km} / \mathrm{h}$ \\
\hline Loading volume & $50 \mathrm{~m}^{3}$ \\
\hline Loading area & $35 \mathrm{~m} 3$ \\
\hline Loading length & $11.2 \mathrm{~m}$ \\
\hline Loading width & $2.72 \mathrm{~m}$ \\
\hline Length between the pivot & $10700 \mathrm{~mm}$ \\
\hline Length over buffers & $15740 \mathrm{~mm}$ \\
\hline Width of tracks & $1435 \mathrm{~mm}$ \\
\hline Buffer height & $1060+5-10 \mathrm{~mm}$ \\
\hline Draw gear & ST-9-2/160 - 1500 kN \\
\hline Screw coupler & $1350 \mathrm{kN}$ \\
\hline Towing hook & $1500 \mathrm{kN}$ \\
\hline Buffers & $50 \mathrm{~kJ}$ \\
\hline
\end{tabular}


One of the main objectives of the goal and scope phase of the LCA is to define the boundaries of the studied system. The LCA calculations include all upstream, core, and downstream processes, and within the system's boundaries are processes related only to the production, operation, and disposal of the rolling stock. Upstream and downstream infrastructure is excluded from the calculations. The preferred method of presenting system boundaries is through the process flow chart. A simplified version of the process flow chart for the SPBC is given in Figure 3.

To analyze the environmental impact, the CML2001 (baseline) method is used. LCA methodology covers three areas of protection: human health, natural environment, and natural resources. The environmental impact categories considered in this study are: (1) acidification potential (AP), (2) climate change (GWP100), (3) eutrophication (EP), (4) ozone layer depletion (ODP), and (5) photochemical oxidation (POCP). A description of every category is given in Table 2 . The CML2001 (baseline) method was chosen as sufficient for this study because it contains all the impact factors that are recognized as relevant and defined by PCR for rolling stock [19].

Table 2 - Definition of impact categories [25]

\begin{tabular}{|c|c|c|}
\hline Impact category & Reference unit & Definition \\
\hline $\begin{array}{l}\text { Acidification } \\
\text { potential (AP) }\end{array}$ & $\mathrm{kg}\left(\mathrm{SO}_{2}-\right.$ eq. $)$ & $\begin{array}{l}\text { The aggregate measure of the acidifying potential of some substances, } \\
\text { calculated through the conversion factor of sulfur oxides and nitrogen and } \\
\text { ammonia into acidification equivalents ( } \mathrm{H}+\text { ion). }\end{array}$ \\
\hline $\begin{array}{l}\text { Climate change } \\
\text { - GWP100 }\end{array}$ & $\mathrm{kg}\left(\mathrm{CO}_{2}-\right.$ eq. $)$ & $\begin{array}{l}\text { Climate change is defined as the impact of human emissions on the } \\
\text { radiative forcing (i.e., heat radiation absorption) of the atmosphere. Global } \\
\text { warming potentials (GWPs) were used as characterization factors to assess } \\
\text { and aggregate the interventions for the impact category climate change. In } \\
\text { particular, GWPs depend on the time horizon T to which integration is } \\
\text { performed. In this case, the time horizon T is equal to } 100 \text { years (GWP100). }\end{array}$ \\
\hline Eutrophication (EP) & $\mathrm{kg}\left(\mathrm{PO}_{4}-\right.$ eq. $)$ & $\begin{array}{l}\text { Eutrophication covers all potential impacts of excessively high environmen- } \\
\text { tal levels of macronutrients, the most important of which are nitrogen }(\mathrm{N}) \\
\text { and phosphorus }(\mathrm{P}) \text {. Nutrient enrichment may cause an undesirable shift in } \\
\text { species composition and elevated biomass production in both aquatic and } \\
\text { terrestrial ecosystems. In addition, high nutrient concentrations may also } \\
\text { render surface waters unacceptable as a source of drinking water. The } \\
\text { areas of protection are the natural environment, natural resources, and the } \\
\text { man-made environment. }\end{array}$ \\
\hline $\begin{array}{l}\text { Ozone layer } \\
\text { depletion (ODP) }\end{array}$ & kg (CFC-11 - eq.) & $\begin{array}{l}\text { Ozone layer depletion refers to the thinning of the ozone layer as a result of } \\
\text { anthropogenic emissions. This causes a greater fraction of solar UV-B } \\
\text { radiation to reach the earth's surface, with potentially harmful impacts on } \\
\text { human health, animal health, terrestrial and aquatic ecosystems, biochemi- } \\
\text { cal cycles and materials. Ozone layer depletion thus impinges on all four } \\
\text { areas of protection: human health, the natural environment, the man-made } \\
\text { environment, and natural resources. }\end{array}$ \\
\hline $\begin{array}{l}\text { Photochemical } \\
\text { oxidation (POCP) }\end{array}$ & $\mathrm{kg}\left(\mathrm{C}_{2} \mathrm{H}_{4}-\right.$ eq. $)$ & $\begin{array}{l}\text { The photo-oxidant formation is the formation of reactive chemical com- } \\
\text { pounds such as ozone by the action of sunlight on certain primary air } \\
\text { pollutants. Those reactive compounds may be injurious to human health } \\
\text { and ecosystems and may also damage crops. Photochemical ozone creation } \\
\text { potentials (POCPs) were used as a characterization factor to assess and } \\
\text { aggregate the interventions for this impact category. }\end{array}$ \\
\hline
\end{tabular}

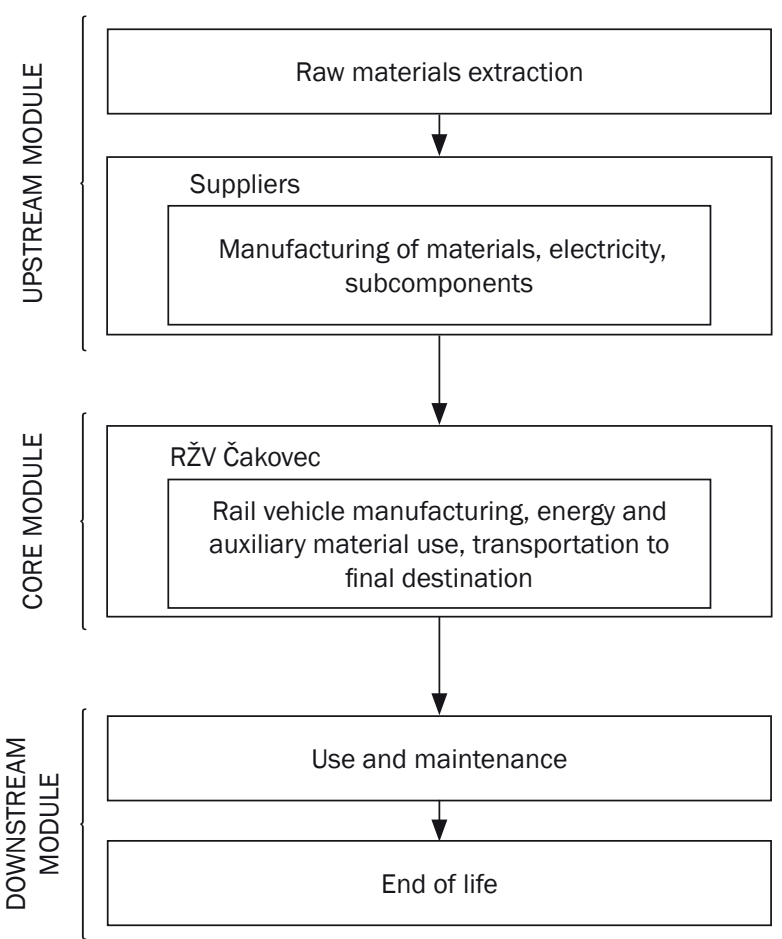

Figure 3 - System boundaries 


\subsection{Life cycle inventory analysis}

Life cycle inventory analysis ( $\mathrm{LCl})$ is considered the core of LCA methodology. Through the life cycle inventory phase, the actual data collection and modeling of the system was done following the directions, i.e., the goal and scope defined in the previous chapter. The inventory phase includes the collection of the required data for flows to and from processes including: (a) elementary flows (use of resources as well as emissions and other interventions with the ecosphere, such as land use), (b) product flows (goods and services both as products of the process (output) but also inputs/ consumables of the process) that link the analyzed process with other processes, (c) waste flows (both wastewater and solid/liquid wastes) that are linked with waste management processes. This is to ensure a complete modeling of the related efforts and environmental impacts. Other information identified in the scope as relevant for the analyzed system, including statistical data (e.g. energy mix, market mix, etc.), process and product characteristics (e.g. functions and functional units), all other data and information, except for those directly related to impact assessment. A flowchart representing system borders and therefore the included processes is presented in Figure 3.

As shown in Table 3, the SPBC is mainly built out of metals (97.72\%). Therefore, manufacturing of metals, their transport, and use will have the most significant impact in the upstream and core modules, as well as in the end of the life phase of the downstream module.

Some of the components used in the SPBC are provided by suppliers. Those components include: bogies, brakes, draw gear, buffer spring, hydraulics, and lifting cylinders. Manufacturing of components by suppliers is not included in the scope of the study, only their transport to the SPBC manufacturing site and production of raw material. The components are manufactured according to the technical specification of the products and have to be in compliance with the assembly methods defined by RŽV Čakovec. Every product during the core phase (i.e., manufacturing) uses resources such as electricity, water, and gas. For the time period from January 2013 to September 2014, the total amount of resources used in RŽV Čakovec was calculated and is shown in Table 4. For the same period, the total amount of working hours used at RŽV Čakovec was calculated and resulted in 310,000.00 working hours (WH).

Table 4 - Resource use: January 2013 to September 2014

\begin{tabular}{||c|c|c||}
\hline \hline Resource & Total use & Unit \\
\hline \hline Electricity & $766,897.00$ & $\mathrm{kWh}$ \\
\hline Gas & $173,940.00$ & $\mathrm{~m}^{3}$ \\
\hline Water & $21,390.00$ & $\mathrm{~m}^{3}$ \\
\hline
\end{tabular}

When performing an LCA study, commissioners have a hard time collecting data because in most cases companies do not have information on how certain resources are allocated to processes, therefore an allocation procedure has to be employed. Table 4 shows the results of resource use for the whole company. In this case, working hours were used to allocate resource use to the SPBC processes. The following formulas were employed to calculate how much of a resource was used per working hour.

$U_{W}=\frac{\text { Amount of water used }}{\text { Total working hours }}$

$U_{G}=\frac{\text { Amount of gas used }}{\text { Total working hours }}$

$U_{E}=\frac{\text { Amount of electricity used }}{\text { Total working hours }}$

$U_{W}$-specific use of water per one working hour $\left[\mathrm{m}^{3} / \mathrm{h}\right]$

$U_{G}$-specific use of gas per one working hour $\left[\mathrm{m}^{3} / \mathrm{h}\right]$

$U_{E}$-specific use of electricity per one working hour $[\mathrm{kWh} / \mathrm{h}]$

The results of the specific use of resources are obtained by dividing the total amount of the resources used in a certain time period by the total number of working hours occurred in the same time period. The results of the specific use of water, gas, and electricity are given below.

$U_{W}=\frac{21390}{310000}=0.0690$

Table 3 - Total amount of used material

\begin{tabular}{||l|c|c|c|c|c||}
\hline \multirow{2}{*}{ Material } & Car body & Bogies and running gears & $\begin{array}{c}\text { Traction and electric } \\
\text { equipment }\end{array}$ & Unit & Percentage \\
\hline \hline Metals & $20,802.40$ & $9,296.50$ & $3,128.20$ & $\mathrm{~kg}$ & $97.72 \%$ \\
\hline Polymers & 0.00 & 3.00 & 207.00 & $\mathrm{~kg}$ & $0.62 \%$ \\
\hline Fluids & 0.00 & 0.00 & 265.00 & $\mathrm{~kg}$ & $0.78 \%$ \\
\hline Elastomer & 0.00 & 0.50 & 1.40 & $\mathrm{~kg}$ & $0.01 \%$ \\
\hline Other & 0.00 & 100.00 & 196.00 & $\mathrm{~kg}$ & $0.87 \%$ \\
\hline Total mass & $20,802.40$ & $9,400.00$ & $3,797.60$ & $\mathrm{~kg}$ & $100 \%$ \\
\hline
\end{tabular}


$U_{G}=\frac{173940}{310000}=0.5611$

$U_{E}=\frac{766897}{310000}=2.4739$

To estimate the number of used resources for the manufacturing of the SPBC, first, a total amount of working hours needed for the production of the SPBC was calculated and resulted in $2,400 \mathrm{~h}$. This amount includes $350 \mathrm{~h}$ needed for painting. Second, the specific use of resources had to be multiplied by the total number of working hours needed for the manufacture of the SPBC using the formulas listed below.

$E_{S P B C}=U_{E} \cdot W H_{S P B C}$

$G_{S P B C}=U_{G} \cdot W H_{S P B C}$

$W_{S P B C}=U_{W} \cdot W H_{S P B C}$

$E_{S P B C} \quad$-electricity used to produce one SPBC [kWh]

$G_{S P B C} \quad$-gas used to produce one SPBC $\left[\mathrm{m}^{3}\right]$

$W_{S P B C} \quad$-water used to produce one SPBC $\left[\mathrm{m}^{3}\right]$

$W_{S P B C}$-working hours needed to produce one SPBC

$E_{S P B C}=2.4739 \cdot 2400=5937.3$

$G_{S P B C}=0.5611 \cdot 2400=1346.6$

$W_{S P B C}=0.0690 \cdot 2400=165.6$

Regarding the transportation for the parts supplied by suppliers, the distances between suppliers' manufacturing sites and the SPBC manufacturing site were determined by calculating the total travel distances between two sites using Google maps. For the materials used directly at the RŽV Čakovec production site (raw and part of the auxiliary materials), the average transportation distance was chosen according to the cut-off rules in PCR [19] for the rolling stocks, which results in $500 \mathrm{~km}$ of road transport. When data about a process was not available, an equivalent of aluminum production was taken into consideration as defined in the cut-off rules of the PCR [19] for rolling stock. A diesel motor drives the SPBC. The data concerning the diesel motor is given in Table 5. The data was obtained from the official technical documentation provided by the manufacturer.

Table 5 - Properties of the SPBC diesel motor

\begin{tabular}{||l|l||}
\hline \multicolumn{1}{|c|}{ Property } & \multicolumn{1}{c|}{ Value } \\
\hline \hline Number of cylinders & 4 \\
\hline Cooling & Liquid \\
\hline Power & $41.5 \mathrm{~kW}$ \\
\hline Engine volume & $3200 \mathrm{~cm}^{3}$ \\
\hline Fuel consumption $(80 \%$ load) & $230 \mathrm{~g} / \mathrm{kWh} ; 8.0 \mathrm{l} / \mathrm{h}$ \\
\hline $\mathrm{NO}_{\mathrm{x}}$ & $5.8 \mathrm{~g} / \mathrm{kWh}$ \\
\hline PT & $0.291 \mathrm{~g} / \mathrm{kWh}$ \\
\hline rpm & $/ \mathrm{min}$ \\
\hline
\end{tabular}

\section{Life cycle impact assessment}

Life cycle impact assessment ( $\mathrm{LCIA}$ ) is a permanently evolving phase of LCA consisting of about 10-15 well-developed impact categories (IC) [4]. According to ISO 14040:2006, [21] LCIA consists of mandatory and optional elements. Primary elements include a selection of impact categories, category indicators, characterization model, assignment of LCl results, and calculation of category indicator results. In this study, the primary data used are from the year 2014. The secondary data are based on the ELCD 3.2 database and correspond to the year of every particular dataset. The timeframe of the ELCD 3.2 dataset is from 2010 to 2015. To calculate the environmental impact, OpenLCA software version 1.41 was used. The environmental impact of the SPBC throughout its life cycle is quantified through environmental impact categories based on the CML 2001 (baseline) method. The CML 2001 method was used in an LCA study in Italy [16] that was assessing the environmental impact of a heavy metro train and another one in Portugal [17] to perform a sensitivity analysis. Figure 4 presents a detailed tree diagram of all processes considered in the LCA, divided into the upstream, core, and downstream modules. The beginning of the arrow represents the phase to which the environmental impact of a certain process is allocated.

When environmental data for certain processes were missing, scientific literature was used to obtain their environmental impact, as well as the cut-off rules defined in the PCR [19] document for the rolling stock. The results of this LCA model are given in the following chapter.

\section{RESULTS}

In this chapter, an analysis of the SPBC life cycle impact on the environment is presented. The results are given in five categories through the three modules of the SPBC lifecycle. Furthermore, the results of the environmental impact are normalized per functional unit and shown in Table 6. To be able to normalize the data, the functional unit and its total value had to be calculated. Calculation of ton kilometers as functional unit considers several assumptions to be made. Firstly, it is assumed that the total lifespan of SPBC will be 35 years. Secondly, the SPBC is going to work $43,750.00$ working hours in total at the average speed of 4.8 kilometers per hour, which results in 210,000.00 kilometers. Thirdly, the average mass of the $80 \%$ SPBC load will be 79.47 tons. When total kilometers travelled are multiplied with the average mass, the result for the functional unit is $16,688,280.00 \mathrm{tkm}$. Because of the specific way of use of the SPBC, the functional unit given in tkm is very low compared to the functional units of rail vehicles. For example, according to [9], a freight 


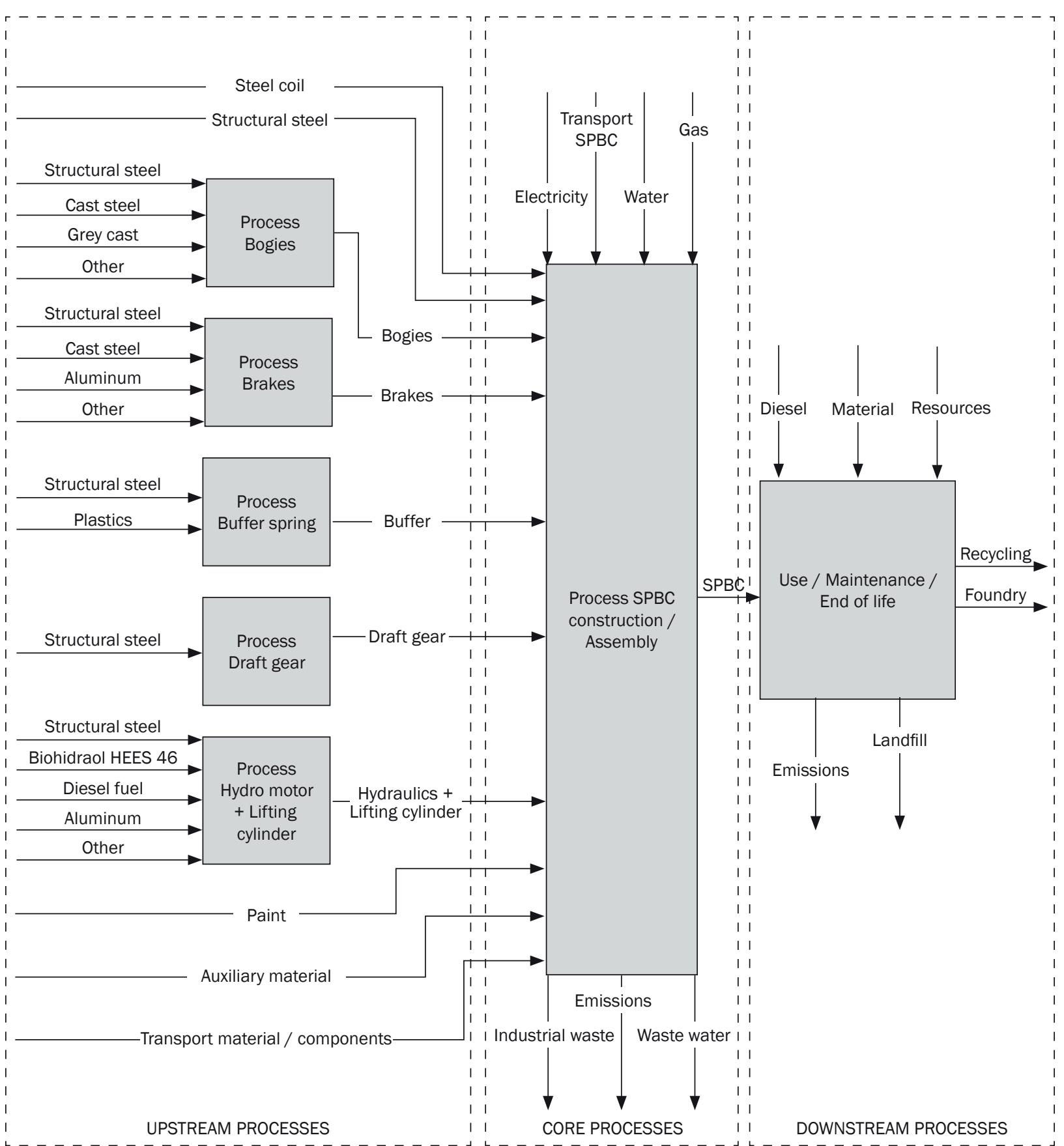

Figure 4 - Process tree diagram of the SPBC life cycle

Table 6 - Environmental impact categories per functional unit

\begin{tabular}{||l|c|c|c|c|c|c||}
\hline \multirow{2}{*}{ Impact category } & Unit & \multirow{2}{*}{ Total } & \multirow{2}{*}{ Upstream } & \multirow{2}{*}{ Core } & \multicolumn{2}{c||}{ Downstream } \\
\cline { 5 - 7 } & & & & & UaM & EoL \\
\hline \hline Acidification potential & $\mathrm{kg}\left(\mathrm{SO}_{2}\right.$ - eq. $) / \mathrm{tkm}$ & $5,378 \mathrm{E}-04$ & $8,285 \mathrm{E}-06$ & $3,065 \mathrm{E}-06$ & $5,264 \mathrm{E}-04$ & $1,096 \mathrm{E}-07$ \\
\hline $\begin{array}{l}\text { Climate change }- \\
\text { GWP100 }\end{array}$ & $\mathrm{kg}\left(\mathrm{CO}_{2}\right.$ - eq. $) / \mathrm{tkm}$ & $7,386 \mathrm{E}-02$ & $2,810 \mathrm{E}-03$ & $7,614 \mathrm{E}-04$ & $7,021 \mathrm{E}-02$ & $7,133 \mathrm{E}-05$ \\
\hline Eutrophication & $\mathrm{kg}\left(\mathrm{PO}_{4}\right.$ - eq. $) / \mathrm{tkm}$ & $1,210 \mathrm{E}-04$ & $7,947 \mathrm{E}-07$ & $3,866 \mathrm{E}-07$ & $1,198 \mathrm{E}-04$ & $1,086 \mathrm{E}-08$ \\
\hline Ozone layer depletion & $\mathrm{kg}(\mathrm{CFC}-11-$ eq. $) / \mathrm{tkm}$ & $1,272 \mathrm{E}-08$ & $2,760 \mathrm{E}-11$ & $6,753 \mathrm{E}-11$ & $1,262 \mathrm{E}-08$ & $3,632 \mathrm{E}-12$ \\
\hline Photochemical oxidation & $\mathrm{kg}\left(\mathrm{C}_{2} \mathrm{H}_{4}\right.$ - eq. $) / \mathrm{tkm}$ & $1,568 \mathrm{E}-05$ & $1,215 \mathrm{E}-06$ & $1,688 \mathrm{E}-07$ & $1,429 \mathrm{E}-05$ & $6,903 \mathrm{E}-09$ \\
\hline
\end{tabular}


train operating at the Bothnia Line in Sweden is estimated to work 3,280,320,000.00 tkm. This difference is mainly due to the fact that general freight trains such as locomotive Re 460 have life performance of 9.6 million kilometers whereas the SPBC has a 45.7 times lower total lifetime performance $(210,000.00$ $\mathrm{km}$ ), hence it operates in different conditions where the average speed of the SPBC is assumed to be 4.8 $\mathrm{km} / \mathrm{h}$.

When analyzing the environmental impact through environmental categories, it can be obtained from Table 4 that the biggest environmental impact is achieved in the use and maintenance phase (UaM) through all impact categories.

\section{DISCUSSION}

The biggest environmental impact of the SPBC through all impact categories is achieved in the use and maintenance phase. Through a detailed analysis of every impact category, we have discovered that the main contributing process to the environmental impact in the use and maintenance phase is the diesel production and consumption process. To be sure that the diesel production and consumption process is the most important contributor, a sensitivity analysis was conducted to check how environmental indicators change when assumptions on the SPBC working hours and, accordingly, assumptions on its diesel consumption change. Therefore, three scenarios were developed, where scenario one was set as the baseline for the sensitivity check. The sensitivity analysis is given below.

For the baseline scenario, it was assumed that the average fuel consumption (diesel fuel) would be 350,000 liters per lifespan of 35 years. To obtain the other two scenarios, the baseline fuel consumption was decreased by $25 \%$ in scenario 2 and increased by $25 \%$ in scenario 3 . For this change to occur, an assumption was made that in scenario 2 the working hours of the SPBC per day will be $25 \%$ lower than in the baseline scenario, and in scenario 3 the working hours will be $25 \%$ higher than in baseline scenario. For scenarios 2 and 3, new environmental impact data was calculated using OpenLCA. Therefore, to calculate the environmental impact in scenario 2, an average fuel consumption of 262,500.00 liters was taken into consideration. For scenario 3, an average fuel consumption of $437,500.00$ liters was taken into consideration. Only data regarding the environmental impact categories would be considered in this sensitivity analysis because those categories present summarized environmental impact data. The percentage of change per every impact category is given in Figure 5.

It can be concluded from the data presented in Figure 5 that change in diesel consumption affected the results through all environmental impact categories, hence the biggest impact was achieved in the categories of eutrophication, ozone layer depletion, and acidification potential. These results were expected because the diesel fuel production and consumption processes are the main contributors to the aforementioned categories. Additionally, depletion of abiotic resources could be considered as an impact category, but, given the relatively low fuel consumption during the SPBC life time, this indicator was not significant and therefore was not taken into consideration. Finally, it is recommended to pay closer attention to the work mode of the SPBC, so that the use of diesel fuel per working hour can be decreased in the future. Furthermore, the use of an electrical propelled system might be considered in the future, but this option will need a more detailed analysis.

\section{CONCLUSION}

This study was intended for internal use and for obtaining the necessary certificates needed for the commercialization of the SPBC, such as the EPD. Cutoff and allocation rules, as well as system boundary definition rules associated with PCR for rolling stock, were followed so the study data could be compared with those of other similar studies in the future. The study has demonstrated the fact that the biggest environmental impacts are mainly associated with the use and maintenance phase, which is similar to the case study analyzing the environmental impact of the heavy metro train [16]. This impact was mainly due to the

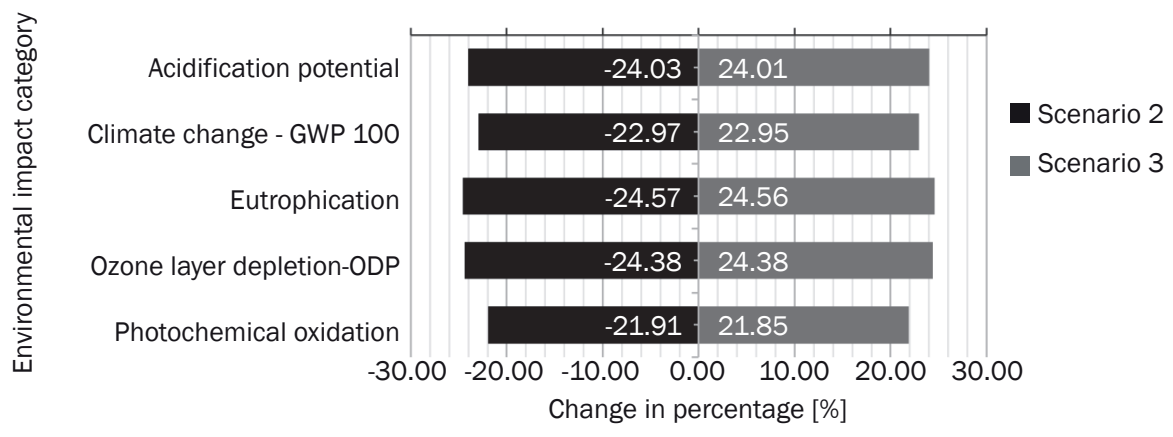

Figure 5 - Environmental impact percentage change through scenarios 
use of energy sources such as crude oil but also due to SPBC maintenance activities and use of energy and other resources.

The sensitivity analysis shows that the use and maintenance phase, specifically the diesel consumption process, has a critical impact on the environmental performance of the SPBC. On the other hand, use of the SPBC, which consumes $8 \mathrm{~L}$ of fuel per working hour on average compared to 3 locomotives averaging $300 \mathrm{~L}$ of diesel fuel per locomotive per hour is already a significant decrease in the environmental impact of railroad maintenance activities. Thus, this significant decrease in the use of diesel fuel for railroad maintenance will contribute to achieving the goal of delivering a minimum $60 \%$ reduction in $\mathrm{GHG}$ emissions from transport by 2050, as set by the European Commission. The environmental impact of one locomotive needed to haul ballast wagons to a worksite, then uncouple it and return to base is not considered in this study.

To build one SPBC, $97 \%$ of the materials required are metals, therefore it is expected that the biggest improvement in the upstream module could be achieved when using more environmentally friendly materials. However, when analyzing the upstream process, results should be taken with caution because the aluminum production process was used when data about a process was missing, resulting in 3.8\% of the total materials used. Additionally, when analyzing the whole life cycle of the SPBC, the use of the aluminum production process as substitute to the missing data has a very low percentage $(0.5 \%)$.

In the life cycle interpretation part of this study, the functional unit of 1 ton per 1 kilometer was used, as this is a standardized unit [19] applied when considering freight vehicles. However, the use of the functional unit of 1 ton per 1 working hour would be more suitable for this kind of self-propelled vehicles and give more accurate results given that such vehicles do not travel many kilometers but are mostly in standby position or move over very short distances up to $1 \mathrm{~km}$. Authors therefore suggest the use of 1 ton per 1 working hour as the functional unit for the LCA of a self-propelled bulk carriage.

As a final remark, it could be concluded that when the SPBC is used in the process of railroad maintenance, its environmental impact is considerably lower than those of the conventional maintenance methods given the fact that the biggest environmental impact occurs in the use and maintenance phase of the SPBC, which is proven in this study.

\section{ACKNOWLEDGMENT}

This research has been carried as part of an EU co-financed project on ECO-Innovation.
Dr. SC. MIRO HEGEDIĆ ${ }^{1}$

E-mail: miro.hegedic@fsb.hr

Dr. sc. NEDELJKO ŠTEFANIĆ ${ }^{1}$

E-mail: nedeljko.stefanic@fsb.hr

Dr. sc. MLADEN NIKŠIĆ ${ }^{2}$

E-mail: mniksic@fpz.hr

${ }^{1}$ Zavod za industrijsko inženjerstvo

Fakultet strojarstva i brodogradnje,

Sveučilište u Zagrebu, Ivana Lučića 5,

10000 Zagreb, Hrvatska

2 Zavod za željeznički promet

Fakultet prometnih znanosti, Sveučilište u Zagrebu

Vukelićeva 4, 10000 Zagreb, Hrvatska

\section{PROCJENA UTJECAJA NA OKOLIŠ SAMOHODNOG VAGONA ZA PRIJEVOZ RASUTOG TERETA KROZ LCA}

\section{SAŽETAK}

Okolišna održivost transportnog sektora je vrlo važan problem današnjice. Europska komisija je postavila cilj smanjenja emisije stakleničkih plinova nastalih od transporta od minimalno 60\% do 2050. godine. Dio ovih smanjenja će doći i iz željezničkog sektora na način da će se procesi održavanja učiniti više prijateljski prema okolišu. Ovaj rad predstavlja rezultate procjene utjecaja na okoliš samohodnog vagona za prijevoz rasutog tereta, inovativnog novog proizvoda koji ima cilj smanjiti utjecaj procesa održavanja pruga na okoliš. U radu je korištena metoda procjene životnog ciklusa proizvoda (LCA), a utjecaj na okoliš je prikazan kroz kategorije utjecaja bazirane na CML 2001 metodi kroz tri glavna modula životnog vijeka samohodnog vagona za prijevoz rasutog tereta: uzvodni, središnji, nizvodni. Novost ovog istraživanja uključuje činjenicu da je ovo prva studija procjene utjecaja životnog ciklusa proizvoda na okoliš izrađena za vagon za prijevoz rasutog tereta, a isto tako autori su predložili korištenje nove funkcionalne jedinice za kategoriju željezničkih vozila za prijevoz tereta. Samohodni vagon za prijevoz rasutog tereta ima najveći utjecaj na okoliš kroz svoj cjeloživotni ciklus u fazi korištenja i održavanja $i$ to u svih pet kategorija utjecaja i uglavnom zbog korištenja dizelskog goriva. SPBC koristi značajno manje goriva nego uobičajena dizelska lokomotiva.

\section{KLUUČNE RIJEČI}

samohodni vagon za prijevoz rasutog tereta; procjena životnog ciklusa; željeznička vozila za prijevoz tereta;

\section{REFERENCES}

[1] European Commission. White Paper - Roadmap to a Single European Transport Area - Towards a competitive and resource-efficient transport system. Directorate - General for Mobility and Transport; 2011.

[2] European Environmental Agency. EEA SIGNALS 2016: Towards clean and smart mobility - Transport and environment in Europe. Copenhagen; 2016.

[3] European Union. EU transport in figures 2016. Publications Office of the European Union. Luxembourg; 2016.

[4] Klöpffer W (ed.). Background and Future Prospects in Life Cycle Assessment. Dordrecht: Springer Netherlands; 2014. 
[5] Egbue O, Wang E, Eseonu C. A Lean Life Cycle Framework for Assessing Product Sustainability. Proceedings of the 2014 Industrial and Systems Engineering Research Conference; 2014. p. 2069-2074.

[6] Merchan A, Belboom S, Léonard A. Environmental impact assessment of rail freight intermodality. Current issues in transportation research - Proceedings of the BIVEC/GIBET transport research days 2015; 2015. p. 77-85.

[7] Duan H, Hu M, Zhang Y, Wang J, Jiang W, Huang Q, Li J. Quantification of carbon emissions of the transport service sector in China by using streamlined life cycle assessment. Journal of Cleaner Production. 2015;95: 109-116.

[8] Von Rozycki C, Koeser H, Schwarz H. Ecology profile of the German high-speed rail passenger transport system, ICE. International Journal of Life Cycle Assessment. 2003;8(2): 83-91.

[9] Stripple H, Uppenberg S. Life cycle assessment of railways and rail transports - Application in environmental product declarations (EPDs) for the Bothnia Line. Gothenburg, Sweden: Swedish Environmental Research Institute; September 2010.

[10] Åkerman J. The role of high-speed rail in mitigating climate change - The Swedish case Europabanan from a life cycle perspective. Transportation Research Part D: Transport and Environment. 2011;16(3): 208-17.

[11] Lee CK, Lee JY, Kim YK. Comparison of environmental loads with rail track systems using simplified life cycle assessment (LCA). WIT Transactions on The Built Environment. 2008;101: 367-72.

[12] Fries N, Hellweg S. LCA of land-based freight transportation: Facilitating practical application and including accidents in LCIA. The International Journal of Life Cycle Assessment. 2014;19(3): 546-57.

[13] Asplan Viak AS. New double track line Oslo-Ski life cycle assessment of the follow line-infrastructure. Norwegian National Rail Administration; 2011.

[14] Banar M, Özdemir A. An evaluation of railway passenger transport in Turkey using life cycle assessment and life cycle cost methods. Transportation Research Part D: Transport and Environment. 2015;41: 88-105.
[15] Chang B, Kendall A. Life cycle greenhouse gas assessment of infrastructure construction for California's high-speed rail system. Transportation Research Part D: Transport and Environment. 2011;16(6): 429-34.

[16] Del Pero F. Delogu M, Pierini M, Bonaffini D. Life Cycle Assessment of a heavy metro train. Journal of Cleaner Production. 2015;87: 787-99.

[17] Jones H, Moura F, Domingos T. Life cycle assessment of high-speed rail: a case study in Portugal. The International Journal of Life Cycle Assessment. 2017;22(3): 410-422.

[18] Ingwersen WW, Stevenson MJ. Can we compare the environmental performance of this product to that one? An update on the development of product category rules and future challenges toward alignment. Journal of Cleaner Production. 2012;24: 102-8.

[19] EPD. Product Category Rules According to ISO 14025:2006. Product Group: UN CPC 495 - Rolling Stock, 2009:05 - Version 2.11; 2014.

[20] ISO 14025:2006. Environmental labels and declarations - Type III environmental declarations - Principles and procedures. Geneva, Switzerland: International Standards Organisation (ISO); 2006.

[21] ISO 14040:2006. Environmental management - Life cycle assessment - Principles and framework. Geneva, Switzerland: International Standards Organisation (ISO); 2006.

[22] ISO 14044:2006. Environmental management - Life cycle assessment - Requirements and guidelines. Geneva, Switzerland: International Standards Organisation (ISO); 2006.

[23] Joint Research Centre, Institute for Environment and Sustainability. General guide for Life Cycle Assessment - Provisions and Action Steps. Luxemburg: European Commission - Publications Office; 2010.

[24] Hauschild MZ, Jeswiet J, Alting L. From Life Cycle Assessment to Sustainable Production: Status and Perspectives. CIRP Annals - Manufacturing Technology. 2005;54(2): 535-554.

[25] Guinée JB. Handbook on Life Cycle Assessment: Operational Guide to the ISO Standards. Dordrecht, Boston: Kluwer Academic Publishers; 2002. 